\section{Power of Networks and} Peer Pressure: An analysis of Slum Sanitation

\section{Program in Mumbai Vivek Anand Asokan ${ }^{*}$ **}

\footnotetext{
${ }^{a}$ Graduate Program in Sustainability Science (GPSS), Graduate School of Frontier Sciences, University of Tokyo, Japan
}

Received: December 16, 2016/ Accepted: November 22, 2017

\begin{abstract}
With the advent of the "Clean India" campaign in India, a renewed focus on cleanliness has started, with a special focus on sanitation. There have been efforts in the past to provide sanitation related services, however, there were several challenges in provisioning. Provision of sanitation is a public health imperative given increased instances of antimicrobial resistance in India. This paper focuses on sanitation provisioning in the city of Mumbai, especially in the slums of Mumbai. The paper compares and contrasts different models of sanitation provision including supply-led provisioning of sanitation by the Indian government to demand-led provisioning of sanitation through a World Bank funded "Slum Sanitation Program" (SSP). The paper also outlines a comparative perspective on the implementation and usage of toilet blocks. The author presents the theory of social networks and positive peer pressure, and argues that these will amplify the effect of other incentives. With the help of an illustration, this paper concludes that the sustainable sanitation policy should look at facilitating and creating the infrastructure as a network and not strictly at building toilet blocks.
\end{abstract}

Keywords: Sanitation; Mumbai; India; Peer pressure.

\begin{tabular}{l}
\hline Abbreviations: \\
\begin{tabular}{|lrl|}
\hline NBA & $:$ & Nirmal Bharat Abhiyan \\
SSP & $:$ & Slum Sanitation Program \\
MCGM & $:$ & Municipal Corporation of Greater Mumba \\
MHADA & $:$ & Maharashtra Housing and Are Development \\
& & Authority \\
NGO & $:$ & Non-Governmental Organisation \\
\hline
\end{tabular}
\end{tabular}

Vivek Anand Asokan

Tel.: +818047327887; E-mail: viv.asok@gmail.com

\begin{tabular}{|lll}
\hline CBO & $:$ & Community-based organisation \\
SDG & & Sustainable Development Goal \\
\hline
\end{tabular}

Sanitation plays a major role in human development and access to it is crucial for growth of an individual's human potential. Sanitation has been accorded an emphasis in the Sustainable Development Agenda as goal 6 of the United Nation's Sustainable Development Goal (SDG). Concurrently, on 2nd October 2014, Swachh Bharat Mission (Clean India Mission) was launched in India. It was declared as a national movement, and the Prime minister of India announced that "A clean India would be the best tribute India could pay to Mahatma Gandhi on his 150 birth anniversary in 2019". The movement is to cover 4,041 statutory cities and towns. The Swachh Bharat Mission replaces the Nirmal Bharat Abhiyan (NBA) scheme [1]. The Clean India mission aims to stop open defecation by 2019 . Appropriate sanitation measures are even more important in cities of India given the challenges of antimicrobial resistance in India. Dr. Timothy R. Walsh, a professor of microbiology at Cardiff University informs,

"India's dreadful sanitation, uncontrolled use of antibiotics and overcrowding coupled with a complete lack of monitoring the problem has created a tsunami of antibiotic resistance that is reaching just about every country in the world," [2](Harris, 2014)

Given these imperatives, a study is needed to evaluate the status of sanitation in Indian cities. The onus of providing sanitation services lies with the municipal and parastatal bodies working at the municipal or state level. This paper looks at sanitation provisional models including supply-led provisioning of sanitation by the government to demand led provisioning of sanitation through a World Bank funded project called "Slum Sanitation Program" (SSP) in the city of Mumbai. The city has seen both supply-led and demand-led models. Therefore, it is a good case study to understand the nuisance of the provision of sanitation services in Urban India. In this paper, the author elucidates the following

1) Sanitation Models provided in the city of Mumbai

2) Effectiveness of these Sanitation Models

3) Incorporating the power of peer pressure while designing sanitation policies

Swachh Bharat Mission has now been expanded all over the country and the city of Mumbai has seen different models. This research can act as a reference for future projects in India. In the Theory of Moral Sentiments, Adam Smith said that "it was human nature to exchange not only goods but also ideas, assistance, and favours out of sympathy" [3]. He 
emphasised the role of social networks for the propagation of ideas, assistance and favours. Recently, Elinor Ostrom noted that,

"International donors and nongovernmental organizations, as well as national governments and charities, have often acted, under the banner of environmental conservation, in a way that has unwittingly destroyed the very social capital - shared relationship, norms, knowledge and understanding - that has been used by resource users to sustain the productivity of natural capital over the ages"[4]

Ostrom also noted the importance of social networks in the process of resource governance. The concept of networks are studied in both social and natural sciences. The author contends that it is the peer to peer relationships in social networks which can play an important role in the construction of toilets. Such an approach is crucial while making policies and to understanding human behaviour in sustainability studies. Although there aren't many cases demonstrating this idea specifically, with the help of an illustration, this paper highlights the impact of peer pressure on social networks in the context of sanitation. The study will be applicable to developing countries which face similar challenges of sanitation. The author hopes the research serves as a catalyst to point out and understand the role played by peer pressure in social networks and their implications for sustainable development in developing countries through the case illustration.

The paper is divided into four parts. The first part of the paper covers the theory of social network and positive peer pressure. The second part of the paper maps the provision of sanitation in slums of Mumbai by different agencies and presents the existing literature on sanitation in Mumbai. In the third part, the author compares different sanitation provision models and illustrates the effect of peer pressure in provision of sanitation services. The methodology of the study is based on literature review, field observation and interviews which were conducted in Shivaji Nagar and Bhandup in Mumbai. The last part involves the discussion

\section{Role of Networks}

Networks are found in form of social networks, metabolic and regulatory networks, and computer networks. [5]. Social networks play an important role in our day to day activities. Festinger, Schachter and Back (1948) made an argument from the field of social psychology that sharing ideas are easier in a denser network. Denser groups have less "free rider" problems [6]. At the same time, weaker ties outside the group play an important role in introducing novelty like new ideas and practices. This is termed as "the strength of weak ties" $[7,8]$. Burt (1992) used the term "Structural Holes" to describe strategic advantage held by weak ties which connect many networks that are not connected otherwise [9]. Social Networks are influenced by both economic and non-economic activities and this feature is termed "social embeddedness" of the economy [10]. These ideas have been used to explain different economic and non-economic outcomes like choice of alliance partners (for example, [11]), decisions to acquire other firms and strategies used to do so [12], the diffusion of corporate governance techniques [13]. The persistence of large family and ethnically oriented business groups in advanced economies, extent and source of innovation and its diffusion, position in a social group and its central influence on productivity, role of social networks in real labour markets are also explained by the social networks [14]. Based on these examples it is clear that social networks are crucial for the flow of ideas and practices. Social networks play an important role in reward and punishment. Social networks lead to the creation of trust within the network.

In the field of sociology, using social network analysis Blau and Schwartz in 1984 stressed that the societies without any group affiliation would have the highest social integration [15]. It also implied that for a complex idea to spread, it was better to reduce social boundaries. This could entail that in a highly diverse population with no social boundary; there would be people with no common interest. This leads to erosion of the social network and social trust. Damon Centola argues that social integration with no group boundaries is important to a point [16]. However, after a certain threshold, it is important that group boundaries are maintained. This permits a population which has some similarities to allow for creation and diffusion of complex ideas within the population. Diffusion of the idea to groups outside the group boundaries is possible by the interaction of members in overlapping groups.

Humans acquire knowledge easily by social learning through examples and iterative processes rather than arguments and reasoning [17]. The research of diffusion of smartphone apps found that people interacting through face to face interaction had increased chances of sharing the app in comparison to little face to face interaction. The study was based on research conducted using mobile phone data for 65 young families over a period of 12 months. Based on data collected about euro/dollar trading from 1.6 million eToro users, a study found that social learning played an enormous role [18]. Traders with higher returns were those who balanced the right diversity of ideas from engagement within the group and exploration from outsiders. Peer pressure has been mentioned as a mechanism in evolutionary biology [19]. From studies on this basis using experimental public goods games (PGG), economic models of peer pressure, microfinance institutions and natural resource usage; peer pressure mechanism is found to increase cooperative behaviour [20-24]. The strategy has been used in the case of sanitation in Zambia, India, Bangladesh [25-26]. These 
programs are known to use shaming, as a strategy in these schemes. However, this negative peer pressure might not work if shaming and other such practices are considered to be illegitimate. These negative practices can lead to non-participation or result in reciprocal negative reactions $[27]$

\section{Slums and Mumbai}

Mumbai is India's financial capital with major corporate houses and India's largest stock exchange market located in the city [28]. The city is also the capital of Maharashtra (one of the provinces of Republic of India). In the latest Census, the population under the Municipal Corporation of Greater Mumbai (MCGM) area stood close to 9.3 million rupees [29]. Also in a period of ten years between 2001 and 2011, the population of Mumbai district fell by $5.75 \%$ [29]. Simultaneously a population growth has been recorded in the neighbouring district of Mumbai suburbs and Thane. Thane's population grew by more than $35 \%$. The density of population in Mumbai and Mumbai Suburbs is very high at 19,652 and 20,980 people per square kilometre respectively [29]. In slums of Mumbai, the density will be much higher than the average density of Mumbai given the inequitable distribution of land in the city.

Census 2011 estimates that the proportion of the households in slums to that of the all urban household in Greater Mumbai municipality is at $41.3 \%$. In Mumbai, 201,190 households of the total 637,738 households were using public toilets and other similar services. Similarly, in Mumbai suburb district 870,222 out of 2,027,743 households were dependent on alternate sources like public toilets. 48,898 households in Mumbai Suburb and 9,340 households were defecating in the open. However, these numbers on the ground could be significantly higher than the number quoted in the official census [30]. Many slum dwellers live in cramped areas all across the city due to the skewed land availability and failure of the government to provide public housing to the poor. Continued migration to the city has made the matter worse with increased density in the city. These slums are plagued with many problems with inadequate water and sanitation facilities. There are around 2000 notified slums, and 130 non-notified slums in the city of Mumbai [31](Sarkar et al., 2006). Mumbai slums are part of its thriving informal economy. This informal economy provides cheap labour in Mumbai.

Provision of sanitation is the greatest challenge in these slums due to narrow lanes and high density. The World Bank report states that "Three in four slums in Mumbai are dependent on public toilets. An estimated one person in 20 (or about 420,00o in total) is compelled to defecate in open areas; this represents about six percent of Mumbai's slum area population." Several policies have been implemented however their desired impact has been minimal with a large population living without sanitation [31].

\subsection{MHADA and MCGM Toilets}

MCGM is the public agency, which was responsible for the provision of basic services like water, sanitation to the city at large including the slum dwellers. Maharashtra Housing and Area Development Authority (MHADA), a provincial nodal agency, and other public agencies also had the mandate to extend the services the slum dwellers [31]. Pre-1980's, toilets were constructed through high subsidy framework where the state took the maintenance and operation. However, over a period, they ran into disrepair and were not maintained properly.

The municipal authorities built "pay and use" toilets between 1984 to 1991 and they were given to Sulabh International, an $\mathrm{NGO}$, for 30 years with management contracts [31]. These toilets were built in commercial spaces with a high pedestrian population. This program was intended to cross subsidise construction of toilets in slum areas. The slum improvement wing of the MCGM had constructed community toilets for the slum dwellers, the toilets were constructed on MCGM lands wherever available, and maintenance of the toilets was taken care of by the municipal sweepers. The toilets fell into repair, and the MCGM were unable to maintain them. By the 1990's MHADA went on to construct a large number of toilets in the city of Mumbai. The primary organisation constructing the toilets soon moved from the municipal agency to the parastatal organisation. The bulk of the community blocks were constructed without community consultation and were, typically, a single level battery of 10 seats for use by adults with separate sections for men and women. Toilets had poor cleanliness, restricted time of use, and frequent damage due to lack of water and electricity. The operation and maintenance of these toilets had continued to pose significant challenges since users were not actively involved in the planning and hence had little sense of ownership, and contributed to their rapid dilapidation followed by a public demand for reconstruction [31]. This led to a new model in the provision of sanitation introduced through World Bank.

\subsection{Slum Sanitation Program (SSP)}

The Mumbai Sewage Disposal Project (MSDP) was approved in the year 1995. After deliberation and local pressure, it was decided that the Slum Sanitation Program (SSP) would be added as an additional component in the MSDP. The earlier proposed objective of the project did not include the SSP program. It was included later due to severe criticism of the local NGO's as the project did not cater to the needs of the majority of the citizens of Mumbai. This component specially catered to the slum population of Mumbai. The failure of the previous attempts prompted the development of a new approach in SSP (Slum Sanitation Project). The main aim of the project was to augment the sewerage 
system of Mumbai. The project cost was INR 13.2 billion which included a loan component of INR 8.6 billion by the World Bank. Ten percent of the total cost was allocated for SSP component [32].

The SSP called for demand responsive, participatory approach unlike the supply side solution provided by the Municipal government and parastatal organisation. The program also promised higher technical construction and maintenance standards in comparison to the earlier toilet blocks. There was special provision for building amenities for women, children and caretakers, and for disabled. The program envisioned collaboration with local stakeholders in the creation of toilet blocks. This collaboration included involving local NGO's (Non-Governmental Organisation) and CBO's (Community based organisation). This was done by forming a $\mathrm{CBO}$ whose members could make a financial contribution towards membership. The members would be involved in toilet design and site selection. The NGO's were to facilitate the involvement of the $\mathrm{CBO}$ in the above process. A CBO was formed as a trust /Society under Bombay public trust Act. A family had to pay Rs 100 for an individual, but the maximum amount per family was Rs 500. This was done to express "demand" by the $\mathrm{CBO}$, and the money was deposited in the bank as joint account between CBO and MCGM. The operation and maintained was to be carried out by the CBOs. The CBO and MCGM would sign agreements which would delimit their responsibility. The CBOs were allowed to collect a monthly pass from the members and per user charges from other non-members users to ensure the long-term functioning of the toilet blocks [31].

One of the key features of the SSP was involvement of the community in the decision-making by involving the participation of the community in site selection and toilet block design. The NGOs were actively expected to contributing in the above process. The construction and technical part were to be carried by the contractors or the NGO's depending on the consortium. The MCGM's main role was to coordinate the flow the process between these different stakeholders. The NGOs carried the bulk of the responsibility as they were to be instrumental in creating CBO's by mobilising the slum communities and training the CBO's to run the toilet blocks.

\subsection{Existing Literature on Sanitation in Mumbai}

\subsubsection{Entrepreneurial Spirit}

McFarlane has written extensively on Sanitation in Mumbai and on Slum Sanitation Program. McFarlane in his paper "Governing the contaminated city", identifies similarities between $19^{\text {th }}$ century colonial Mumbai and $21^{\text {st }}$ century postcolonial Mumbai. He notes that there exist differentiated infrastructures provisioning in the city where slum dwellers do not have access to sanitation. He identifies that just like the colonial administration; the current Indian administration holds that the communities in slums are always associated with lack discipline [33,34]. He also identifies the problems with capitalism in which he claims that the sanitation inequality is produced and tolerated. [35]. According to him, a fundamental right to sanitation is neglected by using terms like "cost recovery", "community ownership" and "public-private partnership".

Chakrabarthy (2002) and Mcfarlane (2008) note that SSP attempts to infuse civic consciousness into slum settlements $[33,36]$. The roles played by the NGO's are critical as they are essential to infuse civic consciousness within the slum community. McFarlane (2012) while writing about an entrepreneurial urbanism in the context of Mumbai mentions how the poor are expected to be entrepreneurial especially within the narrative of sanitation [33]. He also mentions this new found portrayal of entrepreneurial spirit celebrates the success of few and proposes a market driven model and has been applied in the SSP where the entrepreneurial spirit of the slum dweller is to be tapped in the provision of sanitation services of slums. Such that, slums with better organised CBO could access the SSP model and implement them.

\subsubsection{Role of NGO's}

The poor condition of toilet blocks built before the SSP forced many slum dwellers, for example in Bhabrekar Nagar, near Malad, to use the nearby Jangal (forest) and defecate in the open. The women also followed this rather than using unclean toilets [33]. SSP allowed for more plural policy infrastructure [37]. McFarlane wanted the plural policy extended to technical infrastructure, in design and construction [33]. However, domination of certain NGOs during the implementation of SSP didn't allow it to fructify.

It was anticipated that people would form CBOs with the help of NGO's and develop an approach to maintain the toilet. However, this did not happen. Instead, the process of building a CBO was facilitated by the NGO's with the help of politicians. Many times it became difficult for these NGO's to build the $\mathrm{CBO}$ given the complex social dynamics and structure in the slums of Mumbai. These NGO's then resorted to the local electoral representatives for support defeating the whole process which lead to client-patron relationship between the elected representatives and the slum dwellers. As noted by Sharma and Bhide (2005), "Currently, in the implementation of SSP, while sanitation services are being delivered concretely, the involvement of people is being given secondary importance" [38]. SPARC as an NGO was given special treatment by both MCGM and World Bank due to the prior record of accomplishment of the NGO [39] (Chaplin, 2011). Also, SPARC was seen as an agency, which could go on to build toilet blocks. However, it is clear that participation took a back seat due to the complex social dynamics of the slums [40]. One of the major ideas behind the SSP has been involvement of the community in the planning, design and then finally the maintenance of the toilets. NGO's were supposedly roped in to play a facilitating 
role in the formation of a CBO. These CBO's were to be involved at different stages of the program. The CBO's involved in the SSP had a very bad track record of following democratic procedures.

\section{Results}

\subsection{Ratlam Model - An obligation of the State}

At the national level, there are a host of national laws and policies which lay down guidelines on urban sanitation like National Urban Sanitation Policy (NUSP) and Water Act, 1974 [41, 42]. However, the onus of providing sanitation services lies with the municipal and parastatal bodies working at the municipal level or state level. The $74^{\text {th }}$ constitutional amendment explicitly mentions that sanitation conservancy is under the ambit of the local bodies [43]. Hence, there are varying local strategies implemented by these agencies. The municipal laws require the owners of the building to take the responsibility to get drainage. However, the policies do not necessarily address the issues of people who cannot afford sanitation services like the slum dwellers. The laws at the municipal level do not explicitly deal with the issues of sanitation in slums.

The Municipal Council, Ratlam v. Shri Vardhichand \& Others case in the Supreme Court of India in 1980 passed a landmark judgement in which it stressed the obligation of the state in the provision of sanitation services [44]. The judgement stressed that a "responsible" municipal government cannot cite financial inability and reinforced that decency and dignity are non-negotiable. The court also pointed to the difference in treatment of the "well to do citizens" and the "slum dwellers" by the municipal authorities. The Court in its landmark judgement said the following,

"The Municipal Council shall, within six months from to-day, construct a sufficient number of public latrines for use by men and women separately, provide water supply and scavenging service morning and evening so as to ensure sanitation. The Health Officer of the Municipality will furnish a report, at the end of the six-monthly term, that the work has been completed. We need hardly say that the local people will be trained in using and keeping these toilets in clean condition. Conscious cooperation of the consumers is too important to be neglected by representative bodies."

The judgement stresses the role of the municipal government in the provision of sanitation services. It also emphasises the need for the government to construct toilets, provide water and scavenging services. However, it called for training of the slum dwellers to maintain the toilets by the government. The court orders also stressed the cooperation of the consumers, in other words, "participation." The Supreme Court judgement stressed the role of the state in the provisioning of sanitation.

\subsection{Comparison of MHADA/MCGM models with SSP}

Table 1 compares the MHADA/MCGM and SSP toilet with the judgement of Supreme Court in the Municipal Council, Ratlam v. Shri Vardhichand \& Others. The Ratlam case judgement called for greater participation of the users, however stressing the obligation of the state in providing the toilet blocks and services like electricity and water. The task of operation and maintenance of toilet blocks was to be carried out by the community. The local body was entrusted with augmenting the skills of the users to maintain the toilet block. The provision of the toilet was need-based by obligating the state to provide services to all.

Theoretically, MHADA and MCGM model implemented by the state was in line with the Ratlam model, nonetheless, with some modification. The local body and parastatal organisation did not give prior importance to the participation of public. The operation and maintenance were to be carried out by the government. In Mumbai, the state failed in the upkeep of the toilet blocks. The state organisation in some instances even stopped the water supply to some toilet blocks and reduced the chance of maintaining the toilet block by the community members. Though the provision of the model was based on need, the system failed due to lack of participation from the community and was effectively hindered by the non-availability of water and electricity services.

Table 1 Comparison of SSP and MHADA to the Supreme Court Judgement

\begin{tabular}{|c|c|c|c|c|}
\hline & $\begin{array}{l}\text { Ratlam } \\
\text { Model }\end{array}$ & $\begin{array}{l}\text { MHA } \\
\text { DA/M } \\
\text { CGM }\end{array}$ & SSP & $\begin{array}{l}\text { Model } \\
\text { Network } \\
\text { based } \\
\text { approach }\end{array}$ \\
\hline Participation & Yes & No & $\begin{array}{l}\text { Yes, but } \\
\text { on the } \\
\text { ground } \\
\text { question } \\
\text { able }\end{array}$ & Yes \\
\hline $\begin{array}{l}\text { Toilet Blocks } \\
\text { provided by } \\
\text { government }\end{array}$ & Yes & Yes & $\begin{array}{l}\text { Yes, but } \\
\text { a small } \\
\text { contribu } \\
\text { tion to } \\
\text { the } \\
\text { commun } \\
\text { ity }\end{array}$ & $\begin{array}{l}\text { Yes with } \\
\text { funding but } \\
\text { design and } \\
\text { construction } \\
\text { with public }\end{array}$ \\
\hline $\begin{array}{l}\text { Others } \\
\text { services like } \\
\text { water and } \\
\text { electricity - } \\
\text { provided by } \\
\text { government }\end{array}$ & Yes & $\begin{array}{l}\text { Yes } \\
\text { but on } \\
\text { the } \\
\text { ground } \\
\text {, that } \\
\text { was } \\
\text { not the } \\
\text { case }\end{array}$ & $\begin{array}{l}\text { Yes but } \\
\text { paid }\end{array}$ & $\begin{array}{l}\text { Yes through } \\
\text { small networks } \\
\text { and paid }\end{array}$ \\
\hline
\end{tabular}




\begin{tabular}{|c|c|c|c|c|}
\hline $\begin{array}{l}\text { Operation } \\
\text { and } \\
\text { Maintenance }\end{array}$ & Users & $\begin{array}{l}\text { Gover } \\
\text { nment }\end{array}$ & $\begin{array}{l}\text { Private } \\
\text { Sector/C } \\
\text { BO's }\end{array}$ & Users \\
\hline $\begin{array}{l}\text { Provision of } \\
\text { Services }\end{array}$ & $\begin{array}{l}\text { Need } \\
\text { Based }\end{array}$ & $\begin{array}{l}\text { Need } \\
\text { Based }\end{array}$ & $\begin{array}{l}\text { Demand } \\
\text { Based }\end{array}$ & Need Based \\
\hline
\end{tabular}

Around $43 \%$ of the SSP toilets had problems on the water supply. The survey found many SSP toilets were looking at alternate arrangements for water. Use of alternate sources of water resulted in increased costs for operation and maintenance of toilet blocks. This translated to an increase in the cost to be paid by the users for using the toilets. The prime source revenue was from monthly users who paid monthly and individual "pay and use" users who paid for every use. Many toilets blocks ran on profit, and this was primarily due to the "pay and use" users as they subsidised the cost of monthly pass users. Unlike the members of $\mathrm{CBO}$, the individual "pay and use" users' were left to pay for every use. As the demand was high and there were few toilets, the users were left with no option but to use the toilets as "pay and use" users. Most of the toilets built under the SSP had been built with a ratio of 1:50 seats in a toilet to the population [45].

In comparison to the MHADA/MCGM toilets, the toilet blocks of SSP has a better technical design pattern, and it catered to building an institutional framework to support the operation and maintenance of the toilet blocks. However, the program fell short on an institutional mechanism to include the need based requirements of the citizens.

On the other hand, the World Bank "Implementation completion report", which was prepared in 2004 but only released in 2010, stated that the "Institutional development impact” had been substantial as SSP set up CBO's which took care of toilet blocks. It noted that sustainability of the project was "likely". However, the report stressed that the focus on efficiency, institutional reforms was critical for longer sustainability. It complemented that the learnings and design of SSP model had been incorporated into the National Sanitation Program.

\subsection{Creation of a Firm and need for Institutional reforms}

The SSP model in comparison to the MHADA/MCGM model is closer to matching the requirement of the Supreme Court judgement. However, the values of the models are different. The SSP model was demand based and concentrated on the economic issues rather on equity issues. The operation and maintenance was taken care of by private agencies or community body organisations. The toilets were constructed from funds of the government and World Bank with the small contribution from the community. Participation was envisaged in the program with flexible options for the community, group and individual toilets. Thus, the creation of SSP created a firm with stakeholders and shareholders. Creation of this firm separated the ownership from control but also production from consumption. MCGM owns the toilets blocks, whereas the CBO's or the NGOs control the functioning of the blocks. At the same time, slum dwellers were turned into consumers and CBO's or NGO's into providers. However, the MCGM, which is to monitor the maintenance of the toilet blocks by CBO's, didn't normally check the toilet blocks. The intervention was only conducted if there was a complaint. However, there are very few complaints as the users did not necessarily complain even if the blocks were not maintained properly [33-35]. Though successively the idea of the firm was created, proper governance mechanisms for stakeholders and shareholders were lacking. It is actively seen that the MCGM which should play a proper role in the regulation under the governance framework which was falling short of its duty especially once the toilet block was constructed.

\subsection{Effects of Peer Pressure in Sanitation Services}

There are case studies of community-led sanitation initiatives in the recognised slums of Mumbai. Based on an interview in 2014 with Shreyashi Dasgupta, one such case was revealed in an interesting observation in one of the slums in Bhandup. It was observed that the local Member of Parliament (MP) encouraged individual sanitation units in slums with the help of MCGM. The MP also worked closely with an NGO, Yuva Pratishthan, to encourage individual sanitation units in the slums ${ }^{\dagger}$. During their initial assessment, the team realised that it was important to install proper sewer lines that would network and facilitate the process of individual sanitation units (as shown in Pic 1). Hence, that process was initiated and over time residents started availing themselves of the benefit of sanitation units. A brief conversation with the MP and the Secretary of Yuvak Pratishthan highlighted that the Sanitation intervention projects were started in the year 2002 with the aim of encouraging sanitation facilities at a household level that would be more hygienic, efficient and cost effective. Initially, it took a while to convince residents, promote the idea and emphasis on the lost cost sanitation options. But after the construction of one or two model units, residents started experimenting with individual toilets. Around 987 toilets were constructed across 10 slums in and around Bhandup since then. An observation exercise was also conducted in some of these newly constructed units. Most of the toilets were compact, well designed, used good materials and was well maintained by the residents. Interaction with a group of residents brought out an interesting discussion (as shown in Pic 2). They were keen

\footnotetext{
† This interview was conducted by the author with Shreyashi Dasgupta, Former Programme Officer who worked with a not-for-profit organization that dealt with water and sanitation in the slums. Shreyashi conducted her field study in the Bhandup slum in 2014 and interacted with the MP and officials of Yuvak Pratishthan. This brief field visit in Bhandup was conducted by Shreyashi as a part of a larger study on understanding community and individual sanitation led initiatives in slums.
} 
to show us their individual sanitation units with great pride and said that some of their toilets were better than their neighbours. Residents had that sense of satisfaction and pleasure and competed against each other to showcase their effort. One of the residents said "Our toilets are quite similar to that of the ones constructed in high rises. Isn't it?" This example has several learning experiences about design, cost, leadership initiatives and space utilisation for individual sanitation units in collaboration with local government authorities and the efforts of the community.

\section{Discussion and Conclusion}

The local NGO Yuvak Pratishthan worked with local stakeholders to get the sewer lines. These sewer lines connected these localities within the city's networked infrastructure. This enabled experimentation and sharing of ideas among the local residents, NGO and the municipal authorities. The construction of new toilets brought a sense of ownership and ease of use. The crucial factor in facilitating this process was the positive peer pressure which helped in other users building and experimenting with the new toilets. This case highlights the power of local social networks and the mechanism of positive peer pressure. The role of social networks and positive peer pressure should be incorporated within the local sanitation policy through SSP-MCGM. Creation of networked infrastructures like micro-sewer and other networked infrastructure should be given higher priority within the policy rather than the construction of the toilet blocks. Creation of this networked infrastructure can facilitate the creation of group toilets and individual toilet blocks. Creation of such an infrastructure has many spill-over effects. To facilitate appropriate sanitation measures, infrastructure emphasis should be given to institutional networks, social networks and the networked infrastructure at different spatial levels. Currently, these networks are not looked concurrently, and this has resulted in lost opportunities. The sanitation policy should explore how the networked infrastructure, institutional networks and social networks can be harmonized and enabled. The example provided here shows a successful model where the institutional and social networks interact with the networked infrastructure. The municipal agency should capture the peer pressure network and incentivise them. This will give the residents easier access to information about the scheme and incentives. The social networks and peer pressure will amplify the effect of other incentives due to spill over from networks. For example, if a new toilet is constructed in a household, there are higher chances that his/her neighbour would also do so. It would be worthwhile to consider the issues of sanitation in Mumbai as a network issue by incorporating the dynamics of the slum, institutions and the infrastructure.

The Ratlam model as envisioned by the Supreme Court judgement talks about a sustainable model theoretically. However, the supply based MHADA/MCGM and demand based SSP model have some differences. The emphasis of participation in SSP is welcome which was denied by the earlier government schemes. However, a focus on economic sustainability derides the whole program as the social benefits from the program are limiting. The SSP model should include the focus on participation and equity which will lead to larger sustainability of the toilet block.

The previous studies mostly reflected the political economy aspect of the SSP. The studies reflect the impact of politics of land and larger impacts of capitalism in shaping an entrepreneurial city in sanitation provision. The review of World Bank reports the economies and institutional aspect of the project. Though the demand based sanitation services are to infuse entrepreneurship, the sad reality is that the implementation of the SSP did not allow the entrepreneurial energy of the residents to flourish. This was lost due to nonparticipation of women, construction of toilet blocks and over-reliance on the NGO's and CBO's.

Since there is a demand for individual toilets among the residents of the slums, there is a need to facilitate that demand into a reality by creating successful models and case studies. The success would rely on connecting the residents by mobilising them through social networks by overcoming the local trappings. Creating networks are costly as the costs are incurred by the intuitions creating the network; however, the benefits are sensed by the wider sections. Creation of networks is also critical and essential to developing these networks for social welfare and pro-social public outcomes. The sanitation policy should look at facilitating and creating this infrastructure as a network and not strictly at building toilet blocks. The excluded have to be included within the ambit of this infrastructure, and the policy measures should focus on these imperatives. The author hopes this case illustration is covered in a holistic fashion to capture the power of peer pressure in networks for furthering sustainable development by protecting environment, maintaining public health and also facilitating human development.

\section{Acknowledgements}

I acknowledge the assistance of Dr. Geetanjoy Sahu and Professor Philippe Cullet for their mentorship while writing this paper. I acknowledge the assistance and help of Shreyashi Dasgupta for sharing her case study to support this research. This research did not receive any other specific grant from funding agencies in the public, commercial, or not-for-profit sectors.

\section{References}

[1] "Restructuring of the Nirmal Bharat Abhiyan into Swachh Bharat Mission". pib.nic.in. Retrieved 2017-06-12.

[2] Harris, Gardiner. (2014, December 3). 'Superbugs' Kill India's Babies and Pose an Overseas Threat. Internationl New York Times. Retrieved from http://www.nytimes.com/2014/12/o4/world/asia/superbugskill-indias-babies-and-pose-an-overseas-threat.html 
[3] Smith, Adam. (1759). Theory of Moral Sentiments. Strand \& Edinburgh: A. Millar; A. Kincaid \& J. Bell.

[4] Ostrom, V. and Ostrom, E. (November 7, 2003). Rethinking Institutional Analysis: Interview at the Mercatus Center, George Mason University.

[5] Newman, M. E. (2006). Modularity and community structure in networks. Proceedings of the National Academy of Sciences of the United States of America, 8577-8582. doi: 10.1073/pnas.0601602103

[6] Festinger, Leon., Stanley, Schachter., and Kurt, Back. (1948). Social Pressures in Informal Groups. Cambridge, Mass. MIT Press.

[7] Granovetter, Mark. (1973). The Strength of Weak Ties. American Journal of Sociology, 78:6, pp. 136o -38o.

[8] Granovetter, Mark. (1983) The Strength of Weak Ties: A Network Theory Revisited. Sociological Theory. 1, pp. 201-33. DOI: $10.2307 / 202051$

[9] Burt, Ronald. (1992). Structural Holes: The Social Structure of Competition. Cambridge, Mass. Harvard University Press.

[10] Granovetter, Mark. (1985). Economic Action and Social Structure: The Problem of Embeddedness. American Journal of Sociology, 91:3, pp. 481-510.

[11] Gulati, Ranjay., and Gargiulo, Martin. (1999). Where do Interorganizational Networks Come From? American Journal of Sociology, 104:5, pp. 1439 - 493. Stable URL: http://www.jstor.org/stable/10.1086/210179

[12] Haunschild, Pamela. (1994). How Much is That Company Worth?:Interorganizational Relationships, Uncertainty and Acquisition Premiums. Administrative Science Quarterly. September, 39, pp. 391- 411 DOI: 10.2307/2393296

[13] Davis, Gerald., and Greve, Henrich. (1999). Corporate Elite Networks and Governance Changes in the 1980s. American Journal of Sociology. 103, pp. 1-37. DOI: 10.1086/231170

[14] Granovetter, Mark. (2005). Business Groups and Social Organization. Pp. 429-450 in Neil Smelser and Richard Swedberg, editors, Handbook of Economic Sociology and edition. Russell Sage Foundation and Princeton University Press

[15] Blau, P., \& Schwartz, J. E. (1984). Crosscutting Social Circles: Testing a Macrostructural Theory of Intergroup Relations. Transaction Publishers.

[16] Centola, D. (2015). The Social Origins of Networks and Diffusion. American Journal of Sociology, 1295-1338. DOI: $10.1086 / 681275$

[17] Rendell, L., Boyd, R., Cownden, D., Enquist, M., Eriksson, K., Feldman, M. W., Laland, K. N. (2010). Why Copy Others? Insights from the Social Learning Strategies Tournament. Science (New York, N.Y.), 328(5975), 208-213. http://doi.org/10.1126/science.1184719

[18] Pan, Wei., Altshuler, Yaniv., Pentland, Alex. 2012. Decoding Social Influence and the Wisdom of the Crowd in Financial Trading Network. Privacy, Security, Risk and Trust (PASSAT), 2012 International Conference on Social Computing (SocialCom), 203-209 Publisher - doi>10.1109/SocialCom-PASSAT.2012.133

[19] Nowak, M. (2006). Five rules for the evolution of cooperation. Science, 314 (5805), 1560-1563 DOI: 10.1126/science.1133755

20] Rand, D. G., Dreber, A., Ellingsen, T., Fudenberg, D. and Nowak, M. (2009). A.Positive interactions promote public cooperation. Science, 325, 1272-1275 DOI: 10.1126/science.1177418

[21] Fehr, E., and Gächter, S. (2002). Altruistic punishment in humans. Nature . 415, 137-140 doi:10.1038/415137a
[22] Kandel, E., and Lazear, E. (1992). Peer pressure and partnerships. Journal of Political Economy 100 (4), 801-817 Stable URL: http://www.jstor.org/stable/2138688

[23] Karlan, D. (2007). Social connections and group banking. The Economic Journal, 117 (517), F52-F84 DOI: 10.1111/j.14680297.2007.02015.X

[24] Van Vugt, M. (2001). Community identification moderating the impact of financial incentives in a natural social dilemma: Water conservation. Personality and Social Psychology Bulletin 27 (11), 1440-1449 doi: 10.1177/01461672012711005

[25] Lawrence, JJ., Yeboah-Antwi, K., Biemba, G., Ram, PK., Osbert, N., Sabin, LL., and Hamer, DH. (2016). Beliefs, Behaviors, and Perceptions of Community-Led Total Sanitation and Their Relation to Improved Sanitation in Rural Zambia. Am J Trop Med Hyg. 94(3):553-62. PMID: 26787149. doi: 10.4269/ajtmh.150335

[26] Pattanayak, SK., Yang, JC., Dickinson, KL., Poulos, C., Patil, SR., Mallick, RK., Blitstein, JL., and Praharaj, P.(2009). Shame or subsidy revisited: social mobilization for sanitation in Orissa, India.." Bull World Health Organ, 87(8): 580-587. doi: 10.2471/BLT.08.057422

[27] Herrmann, B., Thöni, C., and Gächter, S. (2008). Antisocial punishment across societies. Science, 319 (5868), 1362-1367 DOI: 10.1126/science. 1153808

[28] Municipal Corporation of Greater Mumbai. "Mumbai: The Business and Financial Capital of India." Accessed on 24 April 2014.http://www.mcgm.gov.in/irj/portal/anonymous/qlbusines smumbai

[29] Census 2011, Director of Census Operation, Maharashtra. 2013

[30] Census 2011, Household Series Tables- Maharashtra, Households by the availability of the type of latrine Availability. Director of Census Operation, Maharashtra. 2013

[31] Sarkar, Soumik.., Moulik, Soma Ghosh., Sen, Somnath.( 2006). The Mumbai Slum Sanitation Program - Partnering with slum communities for Sustainable Sanitation in a Megapolis, World Bank.

[32] World Bank.2004 (disclosure 2010).India - Bombay Sewage Disposal Project. Washington, DC: World Bank. http://documents.worldbank.org/curated/en/2004/o6/4416611/i ndia-bombay-sewage-disposal-project

[33] McFarlane, Colin. (2008). Sanitation in Mumbai's informal settlements: state, slum and infrastructure. Environment and planning, doi: 10.1068/a39221

[34] McFarlane, Colin. (2012). The entrepreneurial slum: Civil Society, mobility and the coproduction of urban development. Urban Studies, doi: 10.1177/004209801245246o

[35] McFarlane, Colin. (2008). Governing the contaminated city: Infrastructure and sanitation in colonial and post-colonial Bombay. International Journal of Urban and Regional Research. DOI: 10.1111/j.1468-2427.2008.00793.x

[36] Chakrabarthy, Dipesh.( 2002) Habitations of Modernity. University of Chicago Press.

[37] Sanyal, Bishwapriya and Mukhija, Vinit. (2001). Institutional pluralism and Housing delivery: A case of unforeseen conflicts in Mumbai, India. World Development, doi:10.1016/So305750X(01)0oo82-1

[38] Sharma R.N., and Bhide A.(2005). World Bank Funded Slum Sanitation Programme in Mumbai: Participatory Approach and Lessons Learnt. Economic and Political Weekly, Stable URL: http://www.jstor.org/stable/4416538 
[39] Chaplin, Susan. (2011). Indian Cities, sanitation and the state: the politics of the failure to provide. Environment and Urbanisation. doi: 10.1177/0956247810396277

[40]Burra, Sundar., Patel, Sheetal., and Kerr, Thomas. (2003). Community-designed, built and managed toilet blocks in Indian Cities. Environment and Urbanisation. doi: 10.1177/095624780301500202

[41] National Urban Sanitation Policy, Ministry of Urban Developemnt,http://moud.gov.in/policies/NUSPpolicy

[42] Water (Prevention and Control of Pollution) Act, 1974, Ministry of Environment and Forest available at http://www.moef.nic.in/legis/water/watı.html

[43] The Constitution of India (Seventy-Fourth Amendment) Act, 1992

[44] Municipal Council, Ratlamvs Shri Vardhichand\&Ors. 1980 AIR 1622, 1981 SCR (1) 97

[45] World Bank/WSP Mumbai SSP Study. (2005). "Study of the World Bank financed slum sanitation project in Mumbai". 


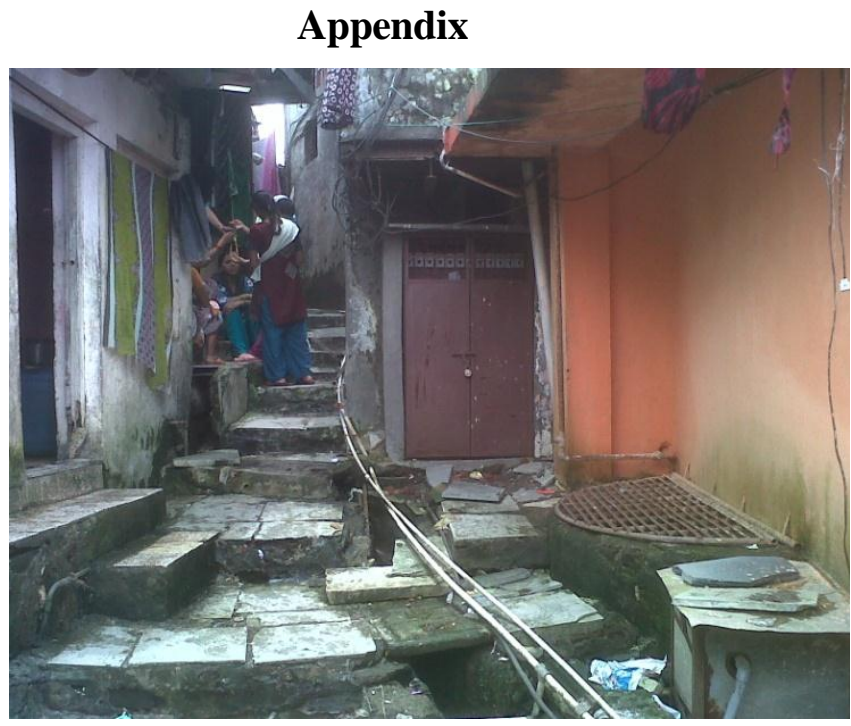

Figure 1 Sewer Lines in Bhandup Slum, Mumbai. Source: Shreyashi Dasgupta, 2014

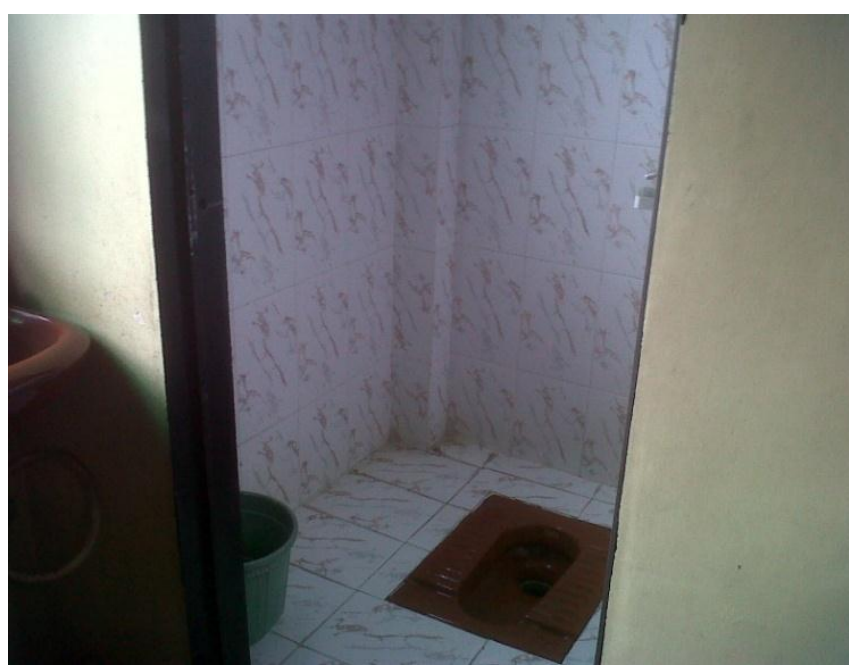

Figure 2 Individual Sanitation units in Bhandup Slum, Mumbai. Source: Shreyashi Dasgupta, 2014. 